\title{
Enhancement of Delayed-Type Hypersensitivity and Induction of Interferon by the Lipophilic Agents DDA and CP-20,961
}

\author{
Cornelis A. Kraaijeveld, Harm Snippe, Theo Harmsen, \\ AND BARRY BENAISSA-TROUW \\ Laboratory of Microbiology. State University of Utrecht, Catharijnesingel 59. \\ 3511 GG Utrecht, The Netherlands
}

Received July 19, 1982; accepted September 13, 1982

\begin{abstract}
The lipophilic amines dimethyl dioctadecyl ammonium bromide (DDA) and $N, N$-dioctadecyl$N^{\prime}, N^{\prime}$-bis(2-hydroxyethyl)propanediamine (CP-20,961) are compared on their capacities to induce interferon, nonspecific protection to viral infection, and enhancement of delayed-type hypersensitivity (DH). DDA, a well-known adjuvant for the induction of $\mathrm{DH}$ is a moderate interferon inducer like CP-20,961. On the other hand, CP-20,961, a known interferon inducer and resembling in structure DDA, is shown to enhance DH to inactivated Semliki Forest virus (SFV). Nonspecific protection to challenge with a lethal dose of either SFV or encephalomyocarditis (EMC) virus was induced on injection of both compounds.
\end{abstract}

\section{INTRODUCTION}

The lipophilic quarternary amine dimethyl dioctadecyl ammonium bromide (DDA) has been shown to enhance the induction of delayed-type hypersensitivity (DH) to sheep red blood cells (1), hapten-carrier complexes (2), and purified inactivated Semliki Forest virus (SFV (3)).

$N, N$-dioctadecyl- $N^{\prime}, N^{\prime}$-bis(2-hydroxyethyl) propanediamine (CP-20,961) is an antiviral drug in mice and humans $(4,5)$. Parental injection of this compound protected mice against otherwise lethal infections with encephalomyocarditis (EMC) virus or SFV. The observed protection was probably mediated by interferon, which was detected in plasma after administration of the drug. Later it was shown by the same and other authors that CP-20,961 also has immunostimulatory properties (6-8).

DDA and CP-20,961 both have two fatty acid chains of equal length, which provide the hydrophobic part of the molecule. The other part of both molecules has a more hydrophilic character. This structural resemblance prompted us to compare the interferon-mediated antiviral properties of DDA and CP-20,961. Moreover, the adjuvanticity of both agents for DH to inactivated SFV was compared.

\section{MATERIALS AND METHODS}

\section{Virus Strains}

The virulent strain SF/LS $10 \mathrm{Cl} / \mathrm{A}$ (9) was received from Dr. C. J. Bradish (Microbiological Research Establishment, Porton Down, Salisbury, U.K.). A large plaque variant of this strain was used for plaque reduction tests. The avirulent strain 
MRS MP 192/7 (10) was obtained from Dr. K. G. Oei (Royal Tropical Institute of Amsterdam, The Netherlands). The preparation of purified inactivated SFV (MRS MP 192/7), of batches of virulent SFV, and of general virological methods have been described previously $(11,12)$. The subcutaneous (sc) $50 \%$ lethal dose $\left(\operatorname{LD}_{50}\right)$ for male BALB/c mice was 15 plaque-forming units (PFU) of the virulent strain.

A virulent strain of encephalomyocarditis (EMC) virus (13) was received from Dr. W. J. C. Boogaerts (Medical Biological Laboratory TNO, Rijswijk, The Netherlands). Batches of virulent virus were prepared and stored as described for the virulent SFV strain (10). The sc $\mathrm{LD}_{50}$ of EMC virus for male BALB/c mice was 16 PFU.

\section{Adjuvants}

DDA was obtained from Eastman Kodak, Rochester, New York. CP-20,961 was a gift from Medical Research Laboratories, Chas Pfizer Inc., Groton, Connecticut. The structure of both compounds is indicated in Table 1.

For induction of nonspecific protection and/or interferon, each chemical was suspended in phosphate-buffered saline (PBS) of pH 7.2 and injected intraperitoneally (ip) in volumes of $0.5 \mathrm{ml}$. For induction of $\mathrm{DH}$, freshly prepared suspensions of the drugs in PBS of $\mathrm{pH} 8$ were mixed with viral antigen and injected in mice.

\section{Animals and Immunization}

Inbred BALB/c mice were bred and maintained in our own animal house. Male mice of about 12 weeks of age were used. Blood was obtained by retroorbital puncture. Inactivated SFV in $0.1 \mathrm{ml}$ PBS of $\mathrm{pH} 8$ mixed with an equal volume containing either $100 \mu \mathrm{g}$ of DDA or $100 \mu \mathrm{g}$ CP-20,961 was injected ic divided over four separate sites in the neighbourhood of draining lymph nodes in axillae and groins.

\section{Assay for $D H$}

DH reactions were measured as the increase in footpad thickness (footpad swelling test) $24 \mathrm{hr}$ after injecting an eliciting dose of diluted virus antigen in a volume of $0.05 \mathrm{ml}$ PBS. The thickness of the footpad was measured with a semielectronic footpad meter with a sensitivity of $0.01 \mathrm{~mm}$ (14). Reactions were recorded and compared with the day when the test dose of antigen was injected, rather than the day upon which the reaction was measured.

\section{TABLE 1}

Structural Formulae of Dimethyl Dioctadecyl Ammonium Bromide (DDA) and $N, N$-Dioctadecyl$N^{\prime}, N^{\prime}$-bis(2-hydroxyethyl)propanediamine (CP-20,961)

-




\section{Interferon Assay}

Interferon activity in sera and supernatant fluids was determined by a modified vesicular stomatitis virus (VSV) plaque reduction test (15). This biological method detects indiscriminately alpha, beta, and gamma interferon activity. Briefly, $5 \times 10^{4}$ mouse fibroblasts (originally clone $\mathrm{L} 929$ ) in volumes of $0.1 \mathrm{ml}$ were seeded in each of 6-mm wells (Titertek, Flow Laboratories, U.K.) and allowed to form monolayers. The cells were maintained for $24 \mathrm{hr}$ at $37^{\circ} \mathrm{C}$ in Eagle's minimal essential medium (MEM) supplemented with $10 \%$ heat-inactivated $\left(30\right.$ min at $56^{\circ} \mathrm{C}$ ) calf serum. Interferon was titrated fourfold in two-step dilutions $(10,20,40,80$, and 160) by adding $0.1-\mathrm{ml}$ quantities of serum or supernatant fluid diluted in MEM to four monolayers. After $18 \mathrm{hr}$ incubation at $37^{\circ} \mathrm{C}$, each monolayer was absorbed with about 40 PFU VSV at room temperature for $1 \mathrm{hr}$. The monolayers were overlaid with $0.05 \mathrm{ml}$ MEM containing $5 \%$ heat-inactivated calf serum and $0.5 \%$ oxoid agar No. 1 (Oxford Ltd, U.K.) and incubated for 18 to $24 \mathrm{hr}$ at $37^{\circ} \mathrm{C}$. The virus plaques were developed with $0.003 \%$ neutral red in Hanks' balanced salt solution. Controls contained 30 to 40 plaques/6-mm well. The serum dilution causing $50 \%$ plaque reduction was found by graphic interpolation. The interferon titer is the inverse value of this dilution. Samples of a standard batch of mouse interferon, kindly provided by the National Institutes of Health (NIH, Bethesda, Md.), were used as a reference with every titration. Generally, the titer of the NIH standard interferon was 2.8 times the titer of our standard mouse interferon.

\section{Cell Suspensions}

Mice were injected ip with DDA, CP-20,961 or PBS. At various times after ip injection of 2-ml Eagle's medium, the mice were killed by cervical dislocation. After slight massage, the abdomen was opened and the peritoneal fluid was collected with a Pasteur pipet $(1.2$ to $1.8 \mathrm{ml}$ ). The peritoneal exudate cells (PEC) from individual mice were centrifuged at low speed $(100 \mathrm{~g})$. Samples of supernatant fluids were taken for interferon titration. After sampling, the cells were washed once with Eagle's medium and brought to a concentration of $10^{7}$ cells $/ \mathrm{ml}$ Eagle's medium. The PEC from individual mice were incubated for $24 \mathrm{hr}$ at $37^{\circ} \mathrm{C}$ in Leighton tubes and, thereafter, a second sample of supernatant fluid was taken for interferon titration.

\section{RESULTS}

\section{$D D A$ and $C P-20,961$ as Adjuvants for $D H$}

Groups of mice were immunized ic with 1500 haemagglutinating units (HAU) of purified inactivated SFV alone or mixed with either $5 \mathrm{mg} \mathrm{CP}-20,961 / \mathrm{kg}$ mice or $5 \mathrm{mg} \mathrm{DDA} / \mathrm{kg}$ mice. Delayed-type hypersensitivity was elicited at Day 6 . It is evident from Fig. 1 that both drugs served as strong adjuvants for the induction of $\mathrm{DH}$.

\section{Nonspecific Protection Induced by DDA against Semliki Forest Virus and Enceph- alomyocarditis Virus}

Mice were injected ip with either PBS, DDA, or CP-20,961. Two different doses of adjuvant were used for the protection experiments: $5 \mathrm{mg} / \mathrm{kg}$ mice or $75 \mathrm{mg} / \mathrm{kg}$ mice. At various intervals after drug administration groups of mice were sc infected with SFV $\left(7 \mathrm{LD}_{50}\right)$ or EMC virus $\left(6 \mathrm{LD}_{50}\right)$. The number of survivors per group were 


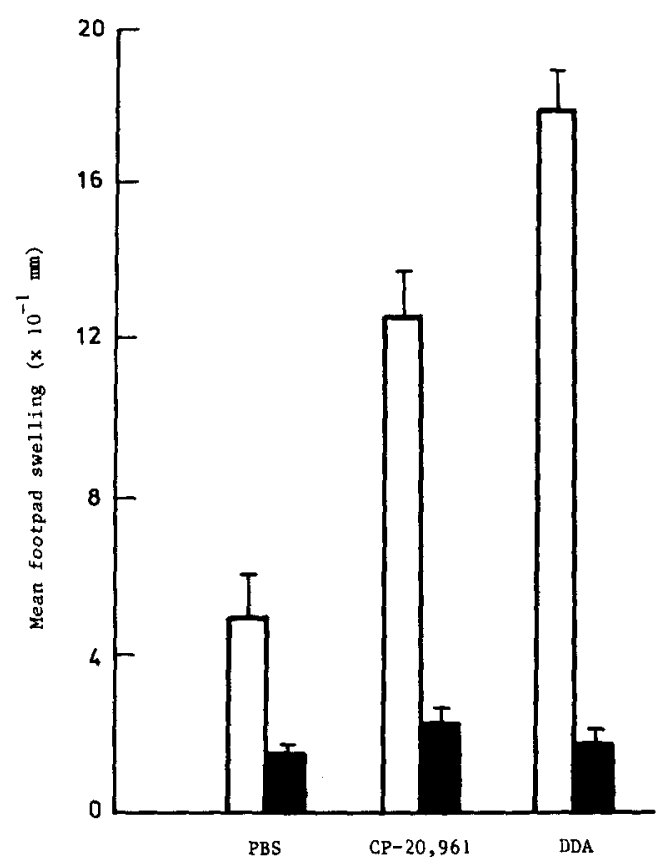

FIG. 1. Effect of DDA and CP-20,96I on delayed-type hypersensitivity. Groups of 4 or 5 mice were immunized ic with 1500 HAU inactivated SFV in PBS only, or with DDA or CP-20,961. Control mice received only PBS or adjuvant. After 6 days all mice were elicited with $450 \mathrm{HAU}$. Footpad swelling of immunized mice (white columns) and controls (black columns) was measured. Vertical bars represent the standard error of the mean.

recorded during 21 days (Table 2). No more deaths occurred after the 14th day of infection. The data indicate that DDA is effective in induction of nonspecific immunity. Substantial numbers of mice survive an otherwise lethal infection of either SFV or EMC virus if $5 \mathrm{mg} \mathrm{DDA} / \mathrm{kg}$ mice is administered 1 day before infection. Moreover, the mean survival time is clearly enhanced in both systems. Higher doses $(75 \mathrm{mg} / \mathrm{kg})$ are slightly more effective. Extension of the interval between injection of the drug and infection abrogates the induction of nonspecific protection.

\section{Antibody Formation after Infection}

To exclude specific antibodies as primary cause of the observed protection, antibody formation after infection with virulent SFV was measured in mice pretreated with DDA or PBS (controls). Blood was collected at Day 4 after infection. Antibody titers of these sera are given in Table 3. Control mice developed considerable amounts of neutralizing antibodies, whereas in mice pretreated with DDA only low levels of antibodies were observed. However, the number of survivors was maximal $(8 / 8)$ in the latter group. In contrast, six out of eight PBS-treated mice died.

\section{Interferon Induction by DDA}

In order to explain the nonspecific protection afforded by DDA, the interferon induction by this drug was studied. Preliminary experiments revealed the existence of interferonlike activity in both sera and peritoneal fluids from mice injected ip 
TABLE 2

Nonspecific Protection Induced in Mice after ip Injection of DDA or CP-20,961 to Either Virulent SFV or EMC Virus ${ }^{a}$

\begin{tabular}{|c|c|c|c|c|c|c|}
\hline \multirow[b]{2}{*}{ Treatment } & \multirow[b]{2}{*}{$\begin{array}{l}\text { Dose } \\
(\mathrm{mg} / \mathrm{kg})\end{array}$} & \multirow{2}{*}{$\begin{array}{c}\text { Interval } \\
\text { between } \\
\text { treatment and } \\
\text { infection } \\
\text { (days) }\end{array}$} & \multicolumn{2}{|c|}{$\begin{array}{l}\text { Mice infected with } \\
7 \mathrm{LD}_{50} \mathrm{SFV}^{b}\end{array}$} & \multicolumn{2}{|c|}{$\begin{array}{l}\text { Mice infected with } \\
6 \mathrm{LD}_{50} \text { EMC virus }\end{array}$} \\
\hline & & & $\begin{array}{c}\text { No. } \\
\text { survivors/ } \\
\text { No. injected }\end{array}$ & $\begin{array}{c}\text { Mean } \\
\text { survival } \\
\text { time (days) }\end{array}$ & $\begin{array}{c}\text { No. } \\
\text { survivors/ } \\
\text { No. injected }\end{array}$ & $\begin{array}{c}\text { Mean } \\
\text { survival } \\
\text { time (days) }\end{array}$ \\
\hline PBS & & -7 & $1 / 16$ & 6.1 & $0 / 8$ & 8.0 \\
\hline PBS & & -1 & $6 / 40$ & 6.4 & $4 / 25$ & 9.1 \\
\hline PBS & & +1 & $0 / 7$ & 6.7 & $\mathrm{NT}^{d}$ & - \\
\hline DDA & 75 & -7 & $1 / 16$ & 6.9 & $0 / 8$ & 7.6 \\
\hline DDA & 75 & -1 & $21 / 32$ & 10.3 & $15 / 16$ & 13.0 \\
\hline DDA & 75 & +1 & $1 / 8$ & 6.6 & $\mathrm{NT}^{d}$ & - \\
\hline DDA & 5 & -1 & $7 / 16$ & 8.2 & $7 / 8$ & 8.0 \\
\hline CP-20,961 & 75 & -1 & $4 / 8$ & 6.7 & $11 / 18$ & 10.1 \\
\hline CP-20,961 & 5 & -1 & $1 / 8$ & 6.4 & $4 / 9$ & 9.2 \\
\hline
\end{tabular}

${ }^{a}$ Results of various experiments compiled.

${ }^{b}$ Mice received sc an injection of $0.1 \mathrm{ml}$ containing $100 \mathrm{PFU}$.

- Mean survival time of nonsurviving mice.

${ }^{d} \mathrm{NT}$, not tested.

with either DDA or CP-20,961, but not from mice injected with PBS. Sera or peritoneal fluids which contained interferon did not neutralize SFV or EMC in a plaque neutralization test (data not given). Threefold higher numbers of PEC $\left(10^{7}\right.$ compared to $3 \times 10^{6}$ cells) were collected from mice injected $24 \mathrm{hr}$ before with DDA $(75 \mathrm{mg} / \mathrm{kg}$ ) than from PBS injected control mice.

In the next experiment, the time dependence of the induction of interferon in both serum and peritoneal fluid was studied. Fourteen mice were injected ip with $1500 \mu \mathrm{g}(75 \mathrm{mg} / \mathrm{kg})$ DDA each. At different intervals $(4,6,8,12,14$, and $16 \mathrm{hr}$ after injection) blood, peritoneal fluid, and PEC were collected. PEC were incubated in Eagle's medium without serum for $24 \mathrm{hr}$ at $37^{\circ} \mathrm{C}$ and the supernatants were also titrated for the presence of interferon. The results of this experiment are presented

\section{TABLE 3}

Antibody Titers $\left(\mathrm{PND}_{50}\right)$ in Mice after Pretreatment with PBS or DDA and Subsequent Challenge with Virulent SFV

\begin{tabular}{clc}
\hline Treatment ${ }^{a}$ & \multicolumn{1}{c}{$\mathrm{PND}_{50}{ }^{b}$ in serum at Day 4 } & $\begin{array}{c}\text { No. survivors/No. injected } \\
\text { at Day } 21\end{array}$ \\
\hline PBS & $18,54,85,>100(5 \times)$ & $2 / 8$ \\
DDA & $0.1 ; 0.2 ; 0.3 ; 0.4 ; 1.0 ; 1.1 ; 1.2 ; 4.6$ & $8 / 8$ \\
\hline
\end{tabular}

\footnotetext{
${ }^{a}$ Groups of 8 mice were injected ip with $0.5 \mathrm{ml}$ PBS or $75 \mathrm{mg}$ DDA $/ \mathrm{kg} 24 \mathrm{hr}$ before sc infection with 100 PFU (7 LD 50 SFV.

${ }^{b}$ If a serum effects a plaque reduction of $50 \%$ at a dilution of $1: 10$, it is indicated as an antibody titer of 10 plaque-neutralizing doses $\left(\mathrm{PND}_{50}\right)$. If no antibody was detectable, the titer is given as 0.1 , which is the lowest level of detection.
} 
TABLE 4

Interferon Titers in Sera and Supernatant Fluids of Peritoneal Exudate Cells at Graded Intervals after ip Injection of $75 \mathrm{mg} \mathrm{DDA} / \mathrm{kg}$

\begin{tabular}{|c|c|c|c|c|c|c|c|}
\hline & \multicolumn{7}{|c|}{ Reciprocal of interferon titer at } \\
\hline & $4 \mathrm{hr}$ & $6 \mathrm{hr}$ & $8 \mathrm{hr}$ & $10 \mathrm{hr}$ & $12 \mathrm{hr}$ & $14 \mathrm{hr}$ & $16 \mathrm{hr}$ \\
\hline Serum $^{a}$ & $\mathrm{ND}^{b}$ & 14 & 16 & 22 & 26 & 23 & 14 \\
\hline $\begin{array}{l}\text { Supernatant fluid } \\
\text { of PEC at } 0 \mathrm{hr}^{c}\end{array}$ & ND & ND & 21 & 97 & 65 & 73 & 40 \\
\hline $\begin{array}{l}\text { Supernatant fluid } \\
\text { of PEC at } 24 \mathrm{hr}^{c}\end{array}$ & ND & 22 & 184 & 58 & 31 & 36 & 35 \\
\hline
\end{tabular}

in Table 4. In serum the interferon titers remained low, but in the corresponding peritoneal fluids, higher titers were demonstrated. An optimum response occurred 10-14 hr after injection with DDA. After harvesting, PEC continued to produce interferon in vitro.

In sera and supernatant fluids of PBS-injected control mice, interferon was not detected (results not shown).

The interferon induced by DDA in both serum and peritoneal fluid was shown to be stable at $\mathrm{pH} 2\left(24 \mathrm{hr}\right.$ at $\left.4^{\circ} \mathrm{C}\right)$.

\section{DISCUSSION}

Dimethyl dioctadecyl ammonium bromide (DDA) induces a nonspecific resistance in mice against SFV and EMC-virus, which may be mediated by interferon. The interferon induced by DDA in serum and supernatant fluid of PEC was stable at $\mathrm{pH} 2\left(24 \mathrm{hr}\right.$ at $\left.4^{\circ} \mathrm{C}\right)$, which indicates that this interferon is presumably of $\alpha$ or $\beta$ specificity (formerly Type 1 interferon). The serum levels of interferon in BALB/ c mice after $75 \mathrm{mg} \mathrm{DDA} / \mathrm{kg}$ are relatively low (Table 4) and almost equal to the interferon titers in plasma of Swiss mice, which were injected with a comparable amount $(50 \mathrm{mg} / \mathrm{kg})$ of the drug CP-20,961 (4). On the other hand, reasonable interferon titers were demonstrable in the peritoneal fluid between 10 and $14 \mathrm{hr}$ after DDA injection. Peritoneal exudate cells collected from mice, which were treated before with DDA ( $75 \mathrm{mg} / \mathrm{kg}$ ), produced interferon in vitro (Table 4). This resembles the results of Niblack et al. (7), who observed the formation of interferon in cultures of peritoneal macrophages explanted from Swiss Webster albino mice $5 \mathrm{hr}$ after injection with CP-20,961 (7). However, interferon induction in vitro, by incubating different amounts of DDA on L-cells, was not detected (results not shown). Both DDA and CP-20,961 activate macrophages $(1,7)$. Peritoneal macrophages showed an increased rate of spreading and increased phagocytic activity after intraperitoneal DDA administration $(1,7)$. Mice injected with CP-20,961 yield macrophages which secrete interferon, but also are activated to kill tumor cells in vitro (7). Such activation of macrophages could possibly result in more effective presentation of antigen by 
macrophages to lymphocytes (1). This may be true for nonreplicating antigens, but it is not easily demonstrated with a replicating virus as an antigen. We found notably higher antibody titers at Day 4 of infection in control mice than in DDA-treated mice (Table 3). The unrestrained virus replication in control mice at an early phase of infection probably causes a massive antigenic stimulation of the immune system, resulting in higher antibody titers than in protected animals, although generally too late to prevent lethal damage, especially to the central nervous system, which is a target organ of Semliki Forest virus (10). Further, it may be relevant for the observed protection to virulent viruses that injection of DDA attracts phagocytic cells to the peritoneal cavity. Threefold higher numbers of PEC were collected from mice who were injected a day before with DDA $(75 \mathrm{mg} / \mathrm{kg}$ ) than from PBS-injected control mice. The increased number of cells in the peritoneal cavity is probably partly responsible for a greater production of interferon.

A dose of $75 \mathrm{mg} \mathrm{DDA} / \mathrm{kg}$, injected ip 7 days before sc virus inoculation, was not in the least protective (Table 2). Absence of protection at Day 7 to SFV after sc injection with the lower dose of $5 \mathrm{mg} \mathrm{DDA} / \mathrm{kg}$ was demonstrated previously (9). Earlier it was demonstrated that ic immunization of mice with inactivated SFV mixed with DDA $(5 \mathrm{mg} / \mathrm{kg})$ resulted in DH 7 days later without demonstrable antibodies (3). In this study, we showed that CP-20,961 is also a good adjuvant for the induction of DH to SFV without detectable antibodies.

In conclusion, DDA and CP-20,961 have similar properties in mice as adjuvants for $\mathrm{DH}$ and as inducers of interferon.

\section{REFERENCES}

1. Gordon, W. C., Prager, M. D., and Carroll, M. C. Cell. Immunol. 49, 329, 1980.

2. Snippe, H., Belder, M., and Willers, J. M. N., Immunology 33, 931, 1977.

3. Kraaijeveld, C. A., Snippe, H., Harmsen, M., and Khader Boutahar-Trouw, B., Archs. Virol. 65, 211, 1980.

4. Hofmann, W. W., Korst, J. J., Niblack, J. F., and Cronin, T. H., Antimicrob. Agents Chemother. 3, 498, 1973.

5. Gatmaitan, B. G., Stanley, E. D., and Jackson, G. G., J. Infect. Dis. 127, 401, 1973.

6. Anderson, A. O., and Reynolds, J. A., J. Reticuloendothel. Soc. Suppl. 26, 667, 1979.

7. Niblack, J. F., Otterness, I. G., Hemsworth, G. R., Wolff, J. S., Hoffman, W. W., and Kraska, A. R., J. Reticuloendothel. Soc. Suppl. 26, 655, 1979.

8. Siddiqui, W. A., Siu-chow Kan, Kramer, K., Case, S., Palmer, K., and Niblack, J. F. Nature (London) 289, 64, 1981.

9. Bradish, C. J., Allner, K., and Maber, H. B., J. Gen. Virol. 12, 141, 1971.

10. Henderson, B. E., Metselaar, D., Kirya, G. B., and Timms, G. L., Bull. W.H.O. 42, 787, 1970.

11. Kraaijeveld, C. A., Harmsen, M., and Khader Boutahar-Trouw, B., Infect. Immun. 23, 219, 1979.

12. Kraaijeveld, C. A., Harmsen, M., and Khader Boutahar-Trouw, B., Infect. Immun. 23, 213, 1979.

13. Bogaerts, W. J. C., and Durville-van der Oord, B. J., Infect. Immun. 8, 528, 1973.

14. Van Dijk, H., Versteeg, H., and Hennink, H. J., J. Immunol. Methods 12, 261, 1976.

15. Epstein, L. B., and McManus, N. H., In "Manual of Clinical Immunology" (N. R. Rose and H. Friedman, Eds.), 2nd ed., pp. 275-283. Amer. Soc. Microbiol., Washington, D.C., 1980. 